ФІЗИКА СОНЦЯ

КІНЕМАТИКА

I ФІЗИКА

НЕБЕСНИХ

ТІЛ том 37 № 12021

doi: https://doi.org/10.15407/kfnt2021.01.003

УДК 523.985 .3

\title{
М. М. Пасечник
}

Головна астрономічна обсерваторія Національної академії наук України вул. Академіка Заболотного 27, Київ, Україна, 03143

rita@mao.kiev.ua

\section{Спектральне дослідження ділянки активної області з бомбою Еллермана та $\mathrm{H}_{\alpha}$-викидами. Хромосфера. Бомба Еллермана}

Представлено результати аналізу спектральних спостережень в лінії $\mathrm{H}_{\alpha}$ ділянки активної області NOAA 11024, на якій розвивалися бомба Еллермана і хромосферні викиди різного виду. Спектральні дані з високою просторовою $і$ часовою роздільною здатністю було отримано на франко-італійському сонячному телескопі THEMIS (о. Тенерифе, Іспанія) 4 липня 2009 р. Час спостережень склав 20 хв. У день спостережень АO перебувала на стадії різкого зростання активності. Профілі лінії $\mathrm{H}_{\alpha}$, отримані для різних періодів розвитку бомби Еллермана, були дуже різноманітними, в основному складалися з декількох компонентів, були асиметричними з надлишком емісії в короткохвильовому крилі. Максимальне збільшення інтенсивності емісійного компонента, порівняно із профілем для ділянки АО без активних утворень (у короткохвильовому крилі - на $73 \%$, а в довгохвильовому - на $35 \%$ відбулося на відстані \pm 0.16 нм від ядра лінії $\mathrm{H}_{\alpha}$. Зміни інтенсивності у крилах лінії $\mathrm{H}_{\alpha}$ вказують на те, щзо під час розвитку бомби Еллермана протягом перших 8 хв відбувалося поступове, а потім протягом 6 хв - імпульсне виділення енергії. Період збільшення яскравості БЕ складався з п'яти піків з інтервалом близько 1 хв. Отримані нами часові зміни променевої швидкості $\left(V_{n p}\right)$ руху хромосферної речовини над областю розвитку БЕ на рівні утворення ядра лінії $\mathrm{H}_{\alpha}$ вказують на те, щзо розподіл швидкостей в иій області був в основному зумовлений розвитком хромосферних викидів. Виділилися два періоди збільшення $V_{n p}$, які складалися з кількох індивідуальних піків - у першій половині спостережень хромосферна речовина в основному рухалася вгору, а у другій - переважав рух вниз. На ділянці без актив- 


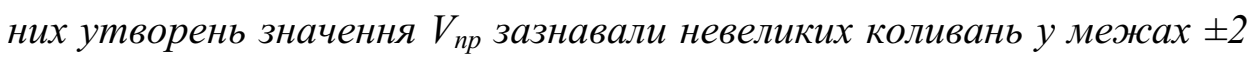
$\kappa м / c$. Над областю розвитку БЕ спостерігалися різного виду $\mathrm{H}_{\alpha}$-викиди. Максимальна швидкість руху вгору у зворотних викидах досягала $-12 \ldots-16 \mathrm{~km} / \mathrm{c}$, опускалася хромосферна речовина уздовж магнітних петель тими ж траєкторіями зі швидкістю удвічі більшою - до $22 \ldots 30 \mathrm{kM} / \mathrm{c}$. У петельному викиді максимальна швидкість висхідного руху з одного боку петлі становила $-7 \mathrm{\kappa M} / \mathrm{c}$, a низхідного - з іншого боку петлі - досягала $18 \mathrm{\kappa м} / \mathrm{c}$. Один з викидів мав ознаки вихрових рухів плазми, про щео свідчать похилі темні смуги на спектрах. Особливості зміни інтенсивності у крилах лінії $\mathrm{H}_{\alpha} i$ променевої швидкості хромосферної речовини вказують на те, щзо бомба Еллермана $i \mathrm{H}_{\alpha}$-викиди, які виникли $i$ розвивалися на досліджуваній нами ділянияі активної області, були результатом магнітних перез'єднань, викликаних виходом нового змієподібного магнітного потоку і його взаємодією з уже наявним магнітним полем або між магнітними петлями самого потоку.

Ключові слова: Сонце, активна область, бомба Еллермана, $\mathrm{H}_{\alpha}$-викиди, магнітні перез'єднання.

\section{ВСТУП}

Спостереження показують, що вихід нового магнітного потоку в активній області (AО) зі складною магнітною структурою, що розвивається, часто супроводжується такими дрібномасштабними подіями в сонячній атмосфері, як мікроспалахи, бомби Еллермана (БЕ), $\mathrm{H}_{\alpha}$-викиди. Всі вони є елементами сонячної активності. У більшості робіт, присвячених вивченню механізму їхнього утворення, зроблено висновок, що вони виникають в результаті процесів магнітних перез'єднань $[2,4,10,11,37,40]$. У багатьох роботах підкреслюється важливість детального вивчення особливостей утворення і розвитку окремих хромосферних структур на основі спостережних даних з високою просторовою та часовою роздільною здатністю. Особливу увагу потрібно приділити тому, як вони взаємодіють 3 іншими динамічними явищами в атмосфері [26].

В роботі [5] було виявлено, що між окремими хромосферними структурами (зокрема віддаленими на значні відстані) є просторовочасові зв'язки. Зв'язок між бомбами Еллермана, $\mathrm{H}_{\alpha}$-викидами і мікроспалахами розглядався в роботах $[6,12,18,23,25,31,36,41,42,44]$. В роботі [12] зроблено висновок, що БЕ і мікроспалахи мають багато спільних рис, таких як короткий час життя, температура, викидоподібні рухи хромосферної речовини і, ймовірно, так само викликаються магнітними перез'єднаннями у нижній сонячній атмосфері. Часто БЕ супроводжуються невеликими короткочасними хромосферними викидами - серджами (surges) [10, 24, 26, 44], що, як вважається, свідчить про магнітне перез'єднання в нижній хромосфері. У роботах [25, $36,41]$ вивчався зв'язок між бомбами Еллермана і хромосферними ви- 
кидами. Автори зазначили, що супутні бомбам Еллермана викиди мали допплерівські швидкості в діапазоні від 20 до 100 км/с, спрямовані як вгору, так і вниз. Зазвичай вони утворювалися через кілька хвилин після появи БЕ і спостерігались протягом $60 . .300$ с. Було також встановлено, що більшість БЕ розташовуються під системами аркових волокон, так званими Arch Filament Systems [44]. В роботі [18] детально розглянуто, як дрібномасштабні перез'єднання з області БЕ генерують періодичні коливання швидкості уздовж магнітної петлі, викликаючи деформацію магнітного поля, достатню для нових перез'єднань більшого масштабу, таких як мікроспалахи.

У роботі [42] описано, що викиди спостерігалися у поглинанні поруч з БЕ через 260 і 920 с після збільшення яскравості БЕ. Спостереження велися в лініях $\mathrm{H}_{\alpha}$ і Са II $\lambda 854.2$ нм. У першому викиді спочатку відбувався рух вгору зі швидкістю 20 км/с, потім - рух вниз зі швидкістю до 40 км/с. Автори зробили висновок, що БЕ і пов'язані з нею викиди є реакцією атмосфери на процес магнітного перез'єднання, який був викликаний появою дрібномасштабного магнітного потоку і відбувався в нижній хромосфері.

У нашій роботі [31] ми досліджували ланцюжок кількох дрібномасштабних подій сонячної активності, їхній вплив один на одного у процесі виникнення і розвитку, особливо зв'язок між БЕ і мікроспалахом, який виник пізніше. На основі аналізу змін променевих швидкостей хромосферної та фотосферної речовини в сонячній магнітній петлі, досліджених нами, а також даних космічних обсерватоpiй GOES, SOHO, STEREO ми запропонували такий сценарій послідовності подій: в області нового магнітного потоку, що піднімався, сформувалася петля, ноги петлі утворили дві пори, і в результаті взаємодії з уже наявним магнітним полем або сусідньою петлею серпантинового магнітного поля відбулося перез'єднання в нижній хромосфері - розвинулася бомба Еллермана, збудження від якої передалося по петлі і викликало повторне перез'єднання — мікроспалах.

Останнім часом з'явилася серія робіт $[13,28,43]$, в яких вивчався зв'язок БЕ і так званих сонячних ультрафіолетових спалахів (UV burst). Термін «УФ-спалах» введено для опису невеликого, інтенсивного, короткочасного підвищення яскравості на УФ-зображеннях активних областей Сонця [43]. Було висловлено припущення, що УФспалахи, як і БЕ, є дрібномасштабними подіями магнітних перез'єднань, що відбуваються в нижній атмосфері на фотосферній або хромосферній висоті [43]. В роботі [28] автори вивчали можливі часові та просторові зв'язки між декількома подіями перез'єднання у різних шарах атмосфери (БЕ і УФ-спалахи), а також їхній зв'язок з викидом серджів у хромосфері. Використовувалися лінії C II (перехідна область), Si IV (перехідна область) і ядро Mg II k (верхня хромосфера). Було зроблено висновок, що ці динамічні явища є частиною однієї і тієї ж системи перез'єднань, що відбуваються послідовно уздовж вертикального або майже вертикального струмового шару, а двонапрям- 
лені потоки вказують місце, де відбувається магнітне перез'єднання. В роботі [13] також отримано висновок, що БЕ і УФ-спалахи іноді утворюються на протилежних кінцях довгого токового шару.

У даній роботі на основі аналізу спектральних спостережень ділянки активної області NOAA 11024, на якій виникла і розвивалася бомба Еллермана і різного виду викиди хромосферної речовини, ми досліджуємо зв'язок між цими дрібномасштабними елементами сонячної активності. У першій частині роботи детально вивчено особливості утворення і розвитку бомби Еллермана під час наших спостережень. Проаналізовано зміни інтенсивності лінії $\mathrm{H}_{\alpha}$ у спектрах, отриманих на різних стадіях розвитку БЕ, а також досліджено зміни променевих швидкостей хромосферної речовини на рівні утворення ядра лінії $\mathrm{H}_{\alpha}$ в області БЕ та її найближчих околицях.

Ми отримали нові дані спостережень для бомб Еллермана. Наші дослідження допоможуть перевірити правильність відомих і побудові нових теоретичних моделей як БЕ, так і $\mathrm{H}_{\alpha}$-викидів.

\section{СПОСТЕРЕЖНИЙ МАТЕРІАЛ}

У даній роботі ми продовжуємо вивчати динаміку атмосфери активної області NOAA 11024 (AO) на основі спектрополяриметричного матеріалу, отриманого на франко-італійському телескопі THEMIS. У день спостережень область перебувала на сонячному диску біля центрального меридіана, іiї координати - S25E02 (-29", -449"), тому всі шукані параметри не зазнавали істотного впливу проєкції. Група плям була біполярною з вкрапленнями великої кількості елементів протилежних полярностей, розташованих уздовж осі, що з'єднувала основні полярності. У різних місцях АО виходили нові магнітні потоки, утворювалися пори і плями (в цей час до її складу входили 17 пор і плям, збільшувалась кількість мікроспалахів [9, 40]. Досліджувана нами ділянка $\mathrm{AO}$, на якій розвинулися бомба Еллермана і $\mathrm{H}_{\alpha}$-викиди, перебувала в області одного з магнітних потоків, що в цей час виходили [38]. Це була серія невеликих ділянок зі змішаною полярністю - так зване серпантинове магнітне поле [8, 12, 38].

У роботі ми використали спектральні дані, отримані О. В. Хоменко на франко-італійському 90-см вакуумному телескопі THEMIS Інституту астрофізики на Канарських островах (Іспанія, острів Тенерифе) з високими просторовою $\left(\sim 1^{\prime \prime}\right)$ і часовою роздільними здатностями. Спостереження велися одночасно в декількох ділянках спектру. Протягом 20 хв $\left(9^{h} 52^{m} \ldots 10^{h} 11^{m}\right.$ UT) було отримано 400 спектрів 3 часовим інтервалом близько 3 с. Ми використали 3 них 36 найбільш якісних. На рис. 1 показано ділянку АО, яку ми досліджуємо, вертикальна лінія вказує положення щілини спектрографа, яка перетинала пору і БЕ, що розвивалася, а також магнітограму АО, отриману інструментом SOHO/MDI в день спостережень. У попередніх наших роботах 


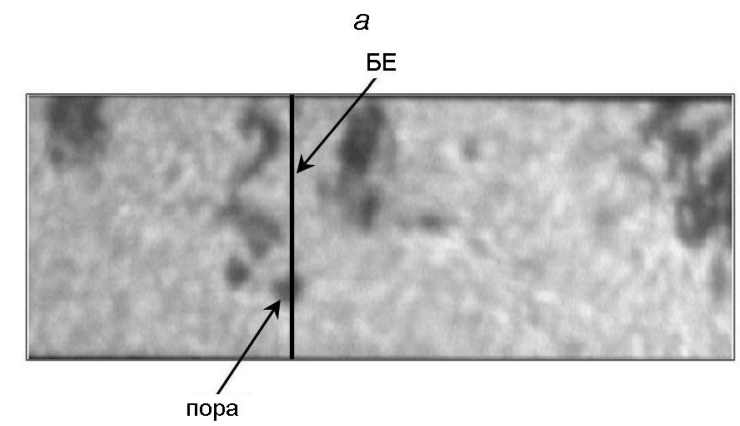

б

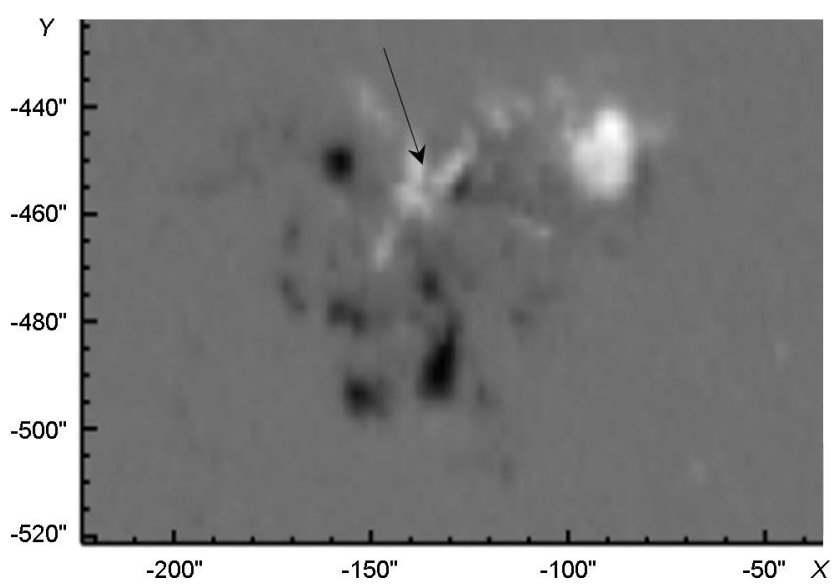

Puc. 1. Зображення досліджуваної ділянки активної області NOAA 110244 липня 2009 р. (a) та магнітограма AO, отримана SOHO/MDI в день спостережень (б). Позитивну і негативну полярності позначено білим і чорним кольором відповідно, стрілкою вказано досліджувану ділянку; вертикальна лінія — положення щілини спектрографа

[20, 21, 31-34] детально описано спектральний матеріал, який ми використовували. У цих роботах було досліджено зміни хромосферних і фотосферних променевих швидкостей в різних активних утвореннях АО - у порах, флоккулах, бомбах Еллермана і в хромосферних викидах, які розвинулися на ділянці АО, що була поруч з ділянкою, яку ми обрали для дослідження в даній роботі.

На рис. 2 представлено $\mathrm{H}_{\alpha}$-спектри, які було отримано в різні моменти спостережень. Ширина ділянки спектру, що включає лінію $\mathrm{H}_{\alpha}$, становила близько 0.6 нм. Перший і шостий спектри належать до першого і останнього моментів спостережень відповідно. Щілина спектрографа перетинала три ділянки AO. Верхня ділянка L2 була без активних утворень і лежала поза областю магнітних потоків, що виходили в цей час. Це дало нам можливість вивчити зміни в сонячній атмосфері на ділянці L1 під дією бомби Еллермана, що розвивалася, i хромосферних викидів. Довжина ділянки L1 становила 10.2 Мм. На всіх спектрах видно дві протяжні емісійні смуги у крилах лінії $\mathrm{H}_{\alpha}$, тоді як центральна частина лінії зайнята поглинанням — це бомба Еллер- 

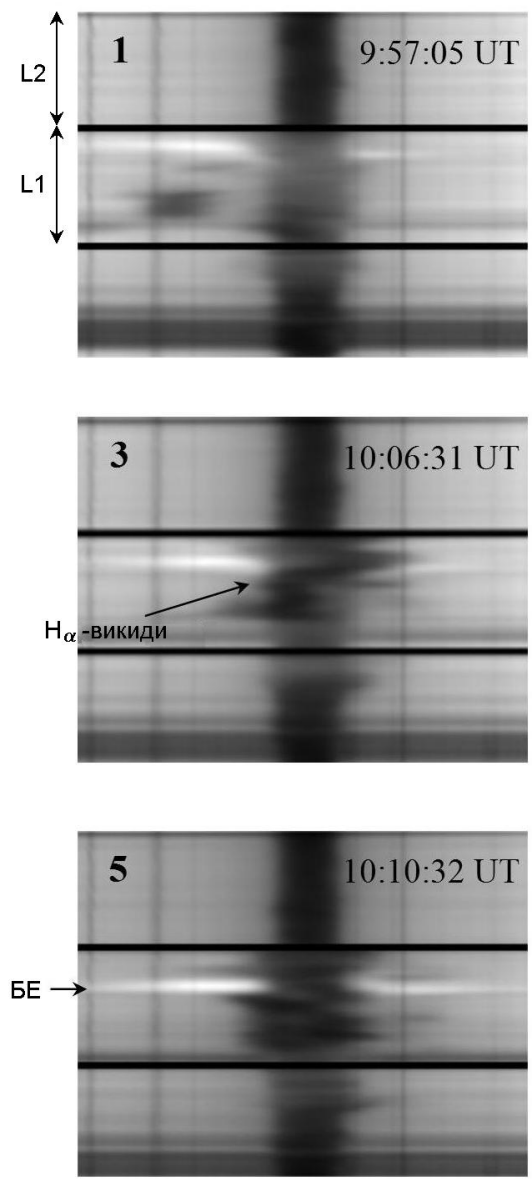
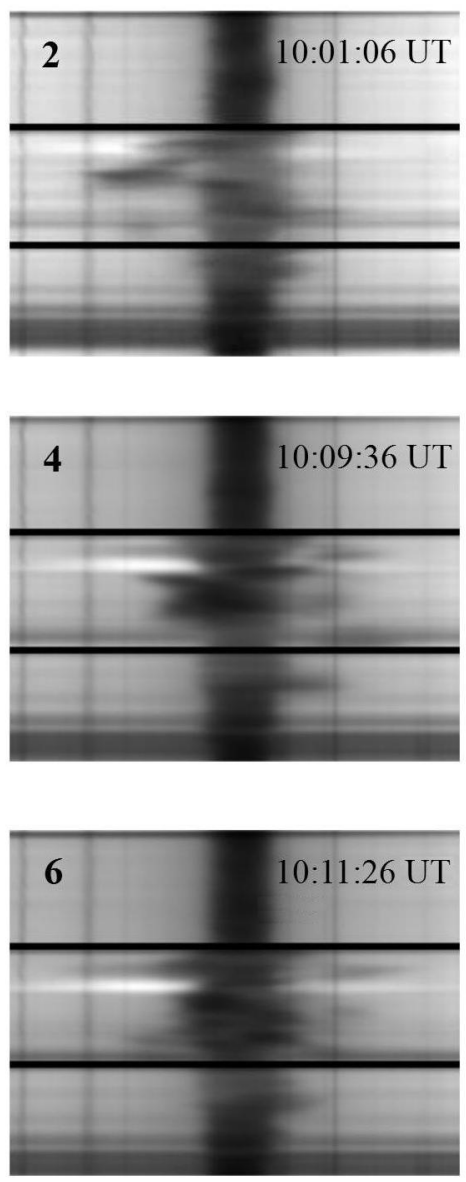

Puc. 2. $\mathrm{H}_{\alpha}$-спектри АО, отримані в різні моменти спостережень (БЕ - бомба Еллермана, L1 - досліджувана ділянка AO, L2 - ділянка АO без активних утворень і поза областю магнітних потоків, що виходили в цей час)

мана, яка розвивалася. Яскравість емісійних смуг змінювалася від одного спектру до іншого, однак більш інтенсивним на всіх спектрах, як і у більшості БЕ, було короткохвильове крило. Для дослідження ми обрали ділянку АО з дуже високою активністю. Під час наших спостережень на ній утворилося багато $\mathrm{H}_{\alpha}$-викидів. На всіх спектрах ïx видно у поглинанні як у довгохвильовому, так і в короткохвильовому крилі лінії $\mathrm{H}_{\alpha}$. Це вказує на те, що у хромосфері спостерігався рух плазми як вгору, так і донизу з дуже різними швидкостями. На першому спектрі викиди видно тільки в синьому крилі $\mathrm{H}_{\alpha}$ (рух вгору - до спостерігача). На спектрі 2 з'явилася темна похила смуга, що перетинає область БЕ, на спектрі 3 вона стала виразнішою - згідно 3 даними [45] під час цього викиду спостерігалися вихрові рухи плазми. На спектрах 3...6 темні смуги видно в обох крилах $\mathrm{H}_{\alpha}$ (рух вгору $\mathrm{i}$ вниз), вони також перетинають і ядро лінії. Видно, що багато викидів складалися з декількох фрагментів, які рухалися з різними швидкостями і мали різну інтенсивність. 


\section{ЗМІНИ ІНТЕНСИВНОСТІ ЛІНІЇ $\mathrm{H}_{\alpha}$}

За відібраними спектрами було отримано $I$-профілі Стокса лінії $\mathrm{H}_{\alpha} 3$ інтервалом, що відповідає відстані 160 км на поверхні Сонця.

Зміни форми профілів. На рис. $3 a$ та 3 в наведено приклади профілів лінії $\mathrm{H}_{\alpha}$ для бомби Еллермана. Рис. $3 a$ показує, як змінювалася форма профілів на різних стадіях розвитку БЕ. Профілі було отримано для центральної частини БЕ. Видно, що форма профілів дуже різноманітна. Як відомо, профілі лінії $\mathrm{H}_{\alpha}$ у спектрах бомб Еллермана складаються з декількох компонентів - профілю поглинання в центрі лінії і профілів випромінювання у крилах лінії. На рис. 3 видно, що зміни в довгохвильовому (червоному) і короткохвильовому (синьому) крилах лінії відбувалися не симетрично. У роботах $[1,11,19]$ було висловлено припущення, що асиметрія крил профілів лінії може бути наслідком різних фізичних умов на шляху потоків, які рухаються в різні боки. Профіль 1 на рис. $3 a$ та 3 н наведено для порівняння, його отримано для ділянки АО без активних утворень і поза областю магнітних потоків, що в цей час виходили (ділянка L2). Зміни форми профілів поглинання залежали від хромосферних викидів, які розвивалися під час наших спостережень, і їхні профілі проєктувалися на профілі БЕ. Викиди це щільні конденсації холодної речовини, яка рухається вздовж магнітних петель. Залежно від того, догори або донизу рухалася речовина викиду і з якою швидкістю, компонент профілю лінії $\mathrm{H}_{\alpha}$, що відповідає викиду, накладався на ядро або на крила профілю $\mathrm{H}_{\alpha}$. За рахунок цього відбувалося викривлення профілю, зміщення його відносно профілю 1 у бік червоного або синього краю спектру.

Профіль 2 на рис. $3 a$ було отримано по спектру першого моменту спостережень (1-й спектр на рис. 2), він трохи зміщений у бік синього краю спектру, інтенсивність в синьому крилі збільшена приблизно на $40 \%$, а у червоному - збільшена на 8 \% відносно профілю 1 . Потрібно зауважити, що у всіх профілів більш яскравим було синє крило, і у більшості профілів максимальне збільшення інтенсивності емісійних компонентів відбулося на відстані приблизно \pm 0.16 нм від ядра лінії (значення відстані коливалися між $\pm 0.15 \mathrm{i} \pm 0.18$ нм). На спектрі отриманому через 4 хв $\left(10^{h} 00^{m} 51^{s} \mathrm{UT}\right)$ на ядро і синє крило лінії проєктувався викид, тому у профілю 3 ядро зміщене у синій бік. У синьому крилі на відстані 0.13 нм від ядра видно компонент, який відповідав викиду, по зсуву цього компонента було визначено швидкість речовини у викиді. Інтенсивність емісійного компонента в червоному крилі цього профілю майже не змінилася - у порівнянні з профілем 1 вона була більшою на 9 \%. Профіль 4 (спектр 3 на рис. 2), через накладення профілю викиду, дуже широкий, його півширина дорівнює 0.2 нм, він удвічі ширший від профілю 1. Ядро профілю і його червоне крило зміщені у червоний бік. Інтенсивність в синьому крилі більша на 47 \%, ніж для профілю 1. Півширини профілів поглинання 5 і 6 були приблизно однаковими і становили близько 0.13 нм, вони відрізнялися 

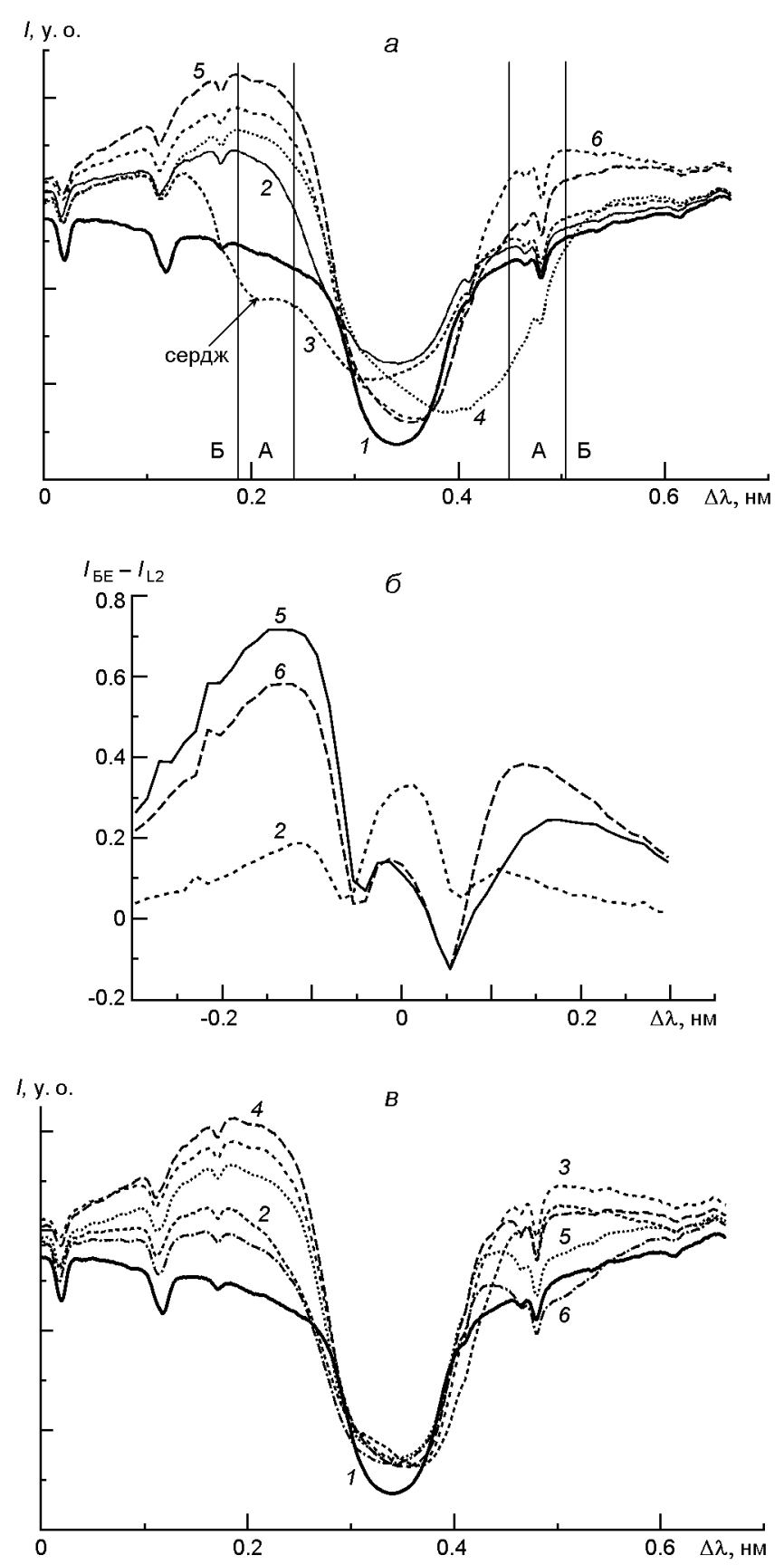

Puc. 3. Приклади профілів лінії $\mathrm{H}_{\alpha}$ для бомби Еллермана: $a-$ профілі $2 \ldots 6$ - для різних моментів спостережень (див. текст), вертикальними лініями А і Б відзначено фотометричні розрізи поперек спектрів на відстані \pm 0.1 та \pm 0.16 нм від центра лінії; $\sigma$ — профілі 2,5 і 6 після віднімання профілю $1 ;$ в - профілі для спектру $10^{h} 10^{m} 32^{s} \mathrm{UT}$, що відповідають центральній частині БЕ (профіль 4) і відстаней \pm 0.32 Мм (профілі 3 і 5 ) та \pm 0.65 Мм (профілі 2 і 6 ) від неї. Профіль 1 (на панелях $a$ і в) наведено для порівняння, він отриманий по спектру ділянки L2 
від півширини профілю для ділянки L2 (0.1 нм) на 30 \%. Інтенсивність у центрі лінії змінювалася залежно від інтенсивності викидів, які відбувалися над областю БЕ. За час наших спостережень максимальне збільшення інтенсивності емісійного компонента в короткохвильовому крилі лінії $\mathrm{H}_{\alpha}$, на 72 \% (профіль 5) і у довгохвильовому крилі на 37 \% (профіль 6), у порівнянні з профілем 1 відбулося в різний час — в $10^{h} 10^{m} 18^{s}$ i $10^{h} 10^{m} 32^{s}$ UT відповідно (в червоному крилі - на 15 с пізніше).

На рис. 36 наведено профілі 2, 5 і 6 після віднімання профілю 1. Видно, що всі профілі демонструють надмірну емісію на синьому і червоному крилах, при цьому емісія в обох крилах лінії виходить за межі спектральної ділянки. Максимальне збільшення інтенсивності в синьому і червоному крилі на профілі 2 відбулося на відстані \pm 0.1 нм від ядра лінії, а на профілях 5 і 6 - на відстані 0.155 і 0.162 нм відповідно. Це вказує на те, що у міру розвитку БЕ збільшення інтенсивності поступово поширювалося вздовж крил лінії, тобто прогрівалися все нижчі шари атмосфери. На профілі 2 спостерігається посилення інтенсивності в ядрі лінії, це означає, що на рівні утворення ядра лінії $\mathrm{H}_{\alpha}$ хромосфера була теж прогріта. Видно, що посилення інтенсивності в крилах лінії відбувалося не симетрично, при цьому синє крило було удвічі інтенсивнішим від червоного. На профілі 5 і 6 накладалися профілі викиду, тому ядра профілів були зміщені в червоний бік, і різниця $I_{\mathrm{БE}}-I_{\mathrm{L} 2}$ мала негативні значення.

На рис. Зв показано, як змінювалася форма профілів по площі БЕ. Наведено профілі, отримані по спектру $10^{h} 10^{m} 32^{s}$ UT (спектр 5 на рис. 2), що відповідають центральній частині БЕ і різним відстаням від неї ( \pm 0.32 і \pm 0.65 Мм). Обрано спектр, на якому область БЕ не перекривається викидами. Профіль 4 показує максимальне збільшення інтенсивності в синьому крилі (на 65 \% порівняно з профілем 1), а профіль 3 - у червоному крилі (на 37 \% порівняно з профілем 1). Ядра профілів 2, 3 і 4 несиметричні і зміщені у бік червоного краю, тоді як ядро профілю 6 - у бік синього. На відстані \pm 0.32 Мм (профілі 3 і 5 ) у синьому і червоному крилах інтенсивність змінювалася відносно профілю 1 таким чином: була збільшена відповідно на 46 і 56 \% та на 26 і $30 \%$, а на відстані \pm 0.65 Мм (профілі 2 і 6 ) — відповідно на 18 і $29 \%$ та на 10 і $6 \%$. Видно, що у всіх профілів яскравішим було синє крило, при цьому яскравість БЕ по площі змінювалась несиметрично.

Інтенсивність в центрі профілів поглинання була більшою на $10 \ldots 14 \%$, ніж у профілі 1 . При збільшенні яскравості у крилах лінії інтенсивність в її центрі у профілів 2, 3 і 4 не змінилася, а у профілів 5 і 6 змінилася мало - у межах $4 \%$, що узгоджується з висновками робіт $[15,16]$.

Зміни інтенсивності лінії $\mathrm{H}_{\alpha}$. На рис. 4 наведено зміни інтенсивності вздовж щілини спектрографа у крилах лінії $\mathrm{H}_{\alpha}$ на відстані \pm 0.1 та \pm 0.16 нм від їі центру (розрізи А і Б на рис. $3 a$ ) у різні моменти спостережень. Відстань \pm 0.16 нм взято тому, що це середнє значення 

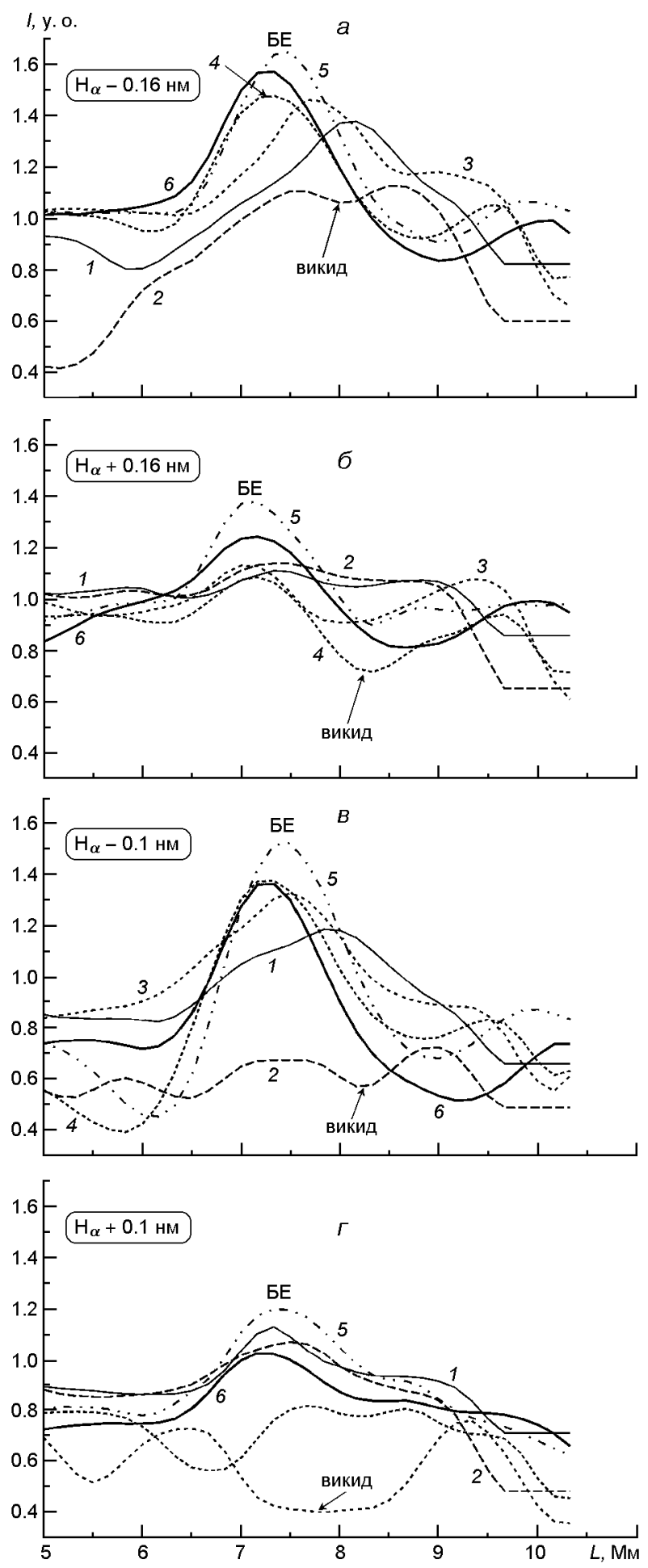

Puc. 4. Зміни інтенсивності вздовж щілини спектрографа у крилах лінії $\mathrm{H}_{\alpha}$ на відстанях \pm 0.1 та \pm 0.16 нм від іï центра (розрізи А і Б на рис. $3 a$ ) в різні моменти спостережень: $9^{h} 57^{m} 05^{s}$, $10^{h} 01^{m} 06^{s}, 10^{h} 06^{m} 31^{s}, 10^{h} 09^{m} 36^{s}, 10^{h} 10^{m} 32^{s}, 10^{h} 11^{m} 26^{s}$ UT (криві $1 \ldots 6$ відповідно) 
відстані, на якій досягалася максимальна інтенсивність емісійних компонентів у крилах лінії $\mathrm{H}_{\alpha}$ для більшості профілів. У більшості робіт $з$ вивчення властивостей БЕ знайдено, що максимум інтенсивності у крилах лінії $\mathrm{H}_{\alpha}$ досягається на відстані \pm 0.1 нм від іiі центра, тому ми дослідили зміни інтенсивності і на цій відстані. Як ми бачили раніше, і в нашій роботі на початку спостережень (рис. 3б) на профілях $\mathrm{H}_{\alpha}$ досліджуваної БЕ максимальне збільшення інтенсивності в синьому і червоному крилі відбувалося на відстані близько \pm 0.1 нм від ядра лінії. На всіх панелях рис. 4 криві 1 і 6 стосуються першого $\left(9^{h} 57^{m} 05^{s} \mathrm{UT}\right)$ і останнього $\left(10^{h} 11^{m} 26^{s} \mathrm{UT}\right)$ моментів спостережень. Видно, що на кривих 1 , отриманих по спектру 1 (рис. 2), емісійна смужка у короткохвильовому крилі яскравіша, ширша і довша (виходить за межі спектральної ділянки), ніж у довгохвильовому крилі. На кривих, отриманих на відстані -0.16 нм (рис. $4 a$ ) i -0.1 нм (рис. 4в) від центра лінії (синє крило) добре виділяється максимум, відповідний області БЕ. У червоному крилі на відстані 0.1 нм (рис. 42) добре видно емісійний пік, тоді як на відстані 0.16 нм (рис. 4б) до цього часу відбулося лише незначне збільшення інтенсивності на $4 \%$.

Криві 2 побудовано по спектру 2 (рис. 2), отриманому через 4 хв після першого. Видно викид, який розвинувся за цей час над областю БЕ. Нижче цієї області в синьому крилі з'явилася темна похила деталь. Як було відзначено раніше, згідно з висновками [45] під час таких викидів відбуваються вихрові рухи плазми, зумовлені магнітним полем. Зменшення інтенсивності в області БЕ на кривих 2 в синьому крилі на відстані -0.16 нм та -0.1 нм від центра лінії відповідає викиду. Розподіл інтенсивності в червоному крилі не змінився.

Криві 3 побудовано для спектру 3 (рис. 2), отриманому через 5.5 хв після спектру 2. Видно, що емісійна смуга в синьому крилі стала яскравішою, але вужчою та коротшою. За цей час темна похила деталь значно збільшилася в розмірі і змістилася у бік довших хвиль, при цьому перетнула ядро лінії і частково перекрила червоне крило. На кривих 3 для синього крила лінії інтенсивність в області БЕ збільшилася, максимум інтенсивності зсунувся відносно кривих 1 і 2 , що вказує на зміну конфігурації магнітного поля. У червоному крилі довжина емісійної смужки збільшилася, пік інтенсивності став добре помітним вже на відстані 0.16 нм. Збудження опустилося у нижчі шари атмосфери. На відстані 0.1 нм область БЕ перекрита хромосферним викидом.

Криві інтенсивності 4 побудовано по спектру 4, отриманому в $10^{h} 09^{m} 36^{s} \mathrm{UT}$ (через 3 хв після попереднього). У синьому крилі на відстані -0.16 нм інтенсивність в області БЕ практично не змінилася, а на відстані -0.1 нм - збільшилася. Максимуми інтенсивності зсунулися відносно кривої 3, тобто конфігурація магнітного поля за цей час знову змінилася. У червоному крилі на відстані 0.16 нм в області БЕ розподіл інтенсивності не змінився, але максимальна величина стала трохи меншою. На відстані 0.1 нм викид частково перекрив область 


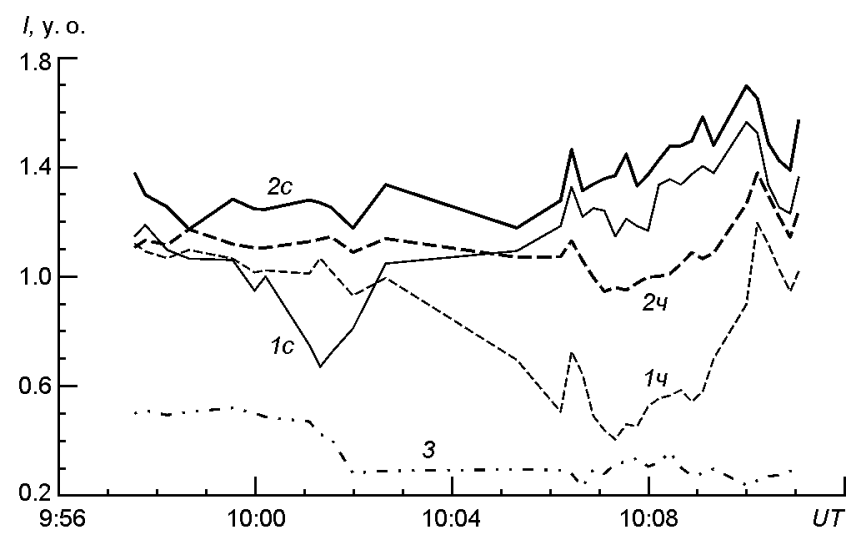

Puc. 5. Зміни з часом інтенсивності емісії в крилах лінії $\mathrm{H}_{\alpha}$ на відстані $\pm 0.1 \mathrm{i} \pm 0.16$ нм від іiі центра: $1 c, 2 c-\mathrm{y}$ «синьому» крилі, $14,2 u-\mathrm{y}$ «червоному» крилі і $3-\mathrm{y}$ центрі лінії для центральної частини БЕ

БЕ. Криві 5 і 6 побудовано за спектрами 5 і 6 (рис. 2), які було отримано наприкінці спостережень 3 інтервалом близько 1 хв. На спектрах видно яскраві емісійні смужки в обох крилах лінії $\mathrm{H}_{\alpha}$. Інтенсивність збільшилася як у синьому, так і у червоному крилі. Максимальне збільшення інтенсивності в області БЕ на всіх панелях показують криві 5 .

За час наших спостережень положення максимуму інтенсивності емісії як в синьому, так і в червоному крилі кілька разів змінювалося. Це $є$ свідченням того, що в області БЕ змінювалася конфігурація магнітного поля.

Розмір області, яку займала БЕ уздовж щілини спектрографа, змінювався $з$ часом: на початку спостережень він становив близько $2.3^{\prime \prime} . .2 .9^{\prime \prime}$, а в кінці спостережень - 1.5". Можливо, розмір площі, яку займала БЕ на початку її розвитку, був більшим через те, що, як було знайдено в роботах $[7,30,32]$, бомби Еллермана розвиваються на ділянках з підвищеною інтенсивністю.

На рис. 5 показано часові криві зміни інтенсивності емісії (світлові криві БЕ) лінії $\mathrm{H}_{\alpha}$ у «синьому» (1c та $2 c$ ) та «червоному» (1ч та 24$)$ крилах на відстані \pm 0.1 нм (1ч і $1 c)$ та \pm 0.16 нм (2ч і $2 c)$ від іï центра, а також у центрі лінії (крива 3) для центральної частини БЕ. Зниження інтенсивності на кривій 1с протягом близько 2.5 хв $\left(9^{h} 59^{m} 55^{s} \ldots\right.$ $\left.10^{h} 02^{m} 31^{s} \mathrm{UT}\right)$ і на кривій $1 ч$ протягом 7 хв $\left(10^{h} 02^{m} 31^{s} \ldots 10^{h} 09^{m} 36^{s} \mathrm{UT}\right)$ відповідає часу, коли над областю БЕ спостерігалися хромосферні викиди. Видно, що зміни інтенсивності у крилах лінії відбувалися з надлишком емісії у синьому крилі, як у більшості бомб Еллермана. Збільшення інтенсивності приблизно на 20 \% в центрі лінії (крива 3) на початку спостережень, можливо, вказує на те, що БЕ утворилася в області активного флоккула. Надалі, як і у всіх БЕ, при збільшенні інтенсивності у крилах лінії інтенсивність в їі центрі змінювалася ма- 
ло і в основному залежала від викидів, які розвинулися над областю БE.

На отриманих нами світлових кривих БЕ можна виділити два періоди. Перший період, протягом якого інтенсивність змінювалася мало, тривав близько 8 хв $\left(9^{h} 57^{m} 05^{s} \ldots 10^{h} 05^{m} 21^{s} \mathrm{UT}\right)$. У синьому крилі за цей час відбувалися коливання інтенсивності, величина яких не перевищувала $16 \%$, а у червоному крилі - $7 \%$.

Другий період тривалістю близько 6 хв $\left(10^{h} 05^{m} 21^{s} \ldots 10^{h} 11^{m} 26^{s} \mathrm{UT}\right)$, протягом якого яскравість БЕ збільшувалася, складався 3 п'яти піків інтенсивності, які спостерігалися 3 інтервалом близько 1 хв. Вони добре виділяються як на синьому, так і на червоному крилі, навіть коли воно перекрите викидом. У порівнянні з першим періодом, за цей час на світових кривих на відстані 0.16 нм від центра лінії інтенсивність в синьому і червоному крилі збільшилася на 41 і $25 \%$, на відстані 0.1 нм - на 38 і 17 \% відповідно. Причому в синьому крилі найвищим був пік з максимумом інтенсивності о $10^{h} 10^{m} 18^{s} \mathrm{UT}$, а в червоному крилі - о $10^{h} 10^{m} 33^{s} \mathrm{UT}$, тобто інтенсивність в синьому крилі досягла максимуму на 15 с раніше, ніж у червоному. У роботі [32] так само було знайдено, що інтенсивність в синьому крилі досягала максимуму на $10 . .25$ с раніше, ніж у червоному.

Такі особливості зміни інтенсивності вказують на процеси імпульсного виділення енергії. Це узгоджується з висновком робіт [14, $27,29,30,35]$ про те, що бомби Еллермана виникають в результаті послідовних і переривчастих магнітних перез'єднань, які призводять до коливань їхньої яскравості з часом. В роботі [14] зроблено висновок, що уривчастість може бути спільною рисою хромосферних магнітних перез'єднань, тому що коливання яскравості лінії $\mathrm{H}_{\alpha}$ спостерігається і у основах хромосферних серджів. Нагадаємо, що ділянка, яку ми досліджуємо, лежала в області спливаючого магнітного потоку у вигляді так званого серпантинового поля, магнітні струмові петлі якого, ймовірно, викликали процес перез'єднання з уже наявним магнітним полем або між сусідніми петлями, що призвело до вивільнення накопиченої енергії [8]. Про магнітні перез'єднання свідчить також і те, що в цей час в області розвитку БЕ спостерігалися викиди хромосферної речовини. Викид, який розвинувся перед збільшенням яскравості БЕ мав ознаки вихрових рухів плазми (темна похила деталь) [45]. В роботі [17] висловлено припущення, що кручена магнітна система може вивільняти свою вільну магнітну енергію за допомогою процесів повторного перез'єднання.

Таким чином, виявлені нами особливості зміни інтенсивності в крилах лінії $\mathrm{H}_{\alpha}$ є свідченням того, що під час першого періоду розвитку БЕ відбувалося поступове, а під час другого періоду - імпульсне виділення енергії. Цей висновок узгоджується з результатами робіт $[11,44]$. У нашій роботі [32] на кривих зміни яскравості БЕ-2 також виділилися два періоди збільшення інтенсивності в крилах лінії $\mathrm{H}_{\alpha}$ : у перший період, який тривав 4 хв, зміни інтенсивності мали плавний 
хід, а другий період, тривалістю близько 5 хв, складався з трьох індивідуальних піків. Це вказує на те, що під час розвитку БЕ-2 відбувалося як поступове, так і імпульсне виділення енергії.

У деяких роботах [22] було висловлено припущення, що розвиток БЕ, як і великих спалахів, можна розділити на три фази: фазу попереднього нагрівання (pre-heating phase), спалахову фазу (flaring phase) та фазу охолодження (cooling phase). Під час першої фази інтенсивність збільшується повільно, але безперервно, а надмірного випромінювання в далеких крилах лінії $\mathrm{H}_{\alpha}$ немає або воно дуже слабке. Автори припускають, що фаза попереднього нагрівання відповідає процесу повільних магнітних перез'єднань, викликаних мікротурбулентністю. Під час другої фази йде процес швидких магнітних перез'єднань, при цьому різко збільшується інтенсивність, а надмірне випромінювання у крилах лінії $\mathrm{H}_{\alpha}$ досягає максимуму. Потім йде коротка фаза охолодження, коли інтенсивність швидко зменшується. У роботах з вивчення бомб Еллермана саме фазу, коли відбувається різке збільшення інтенсивності в крилах лінії $\mathrm{H}_{\alpha}$ в результаті імпульсного виділення енергії, викликаного послідовними переривчастими магнітними перез'єднаннями, називають власне БЕ. Так, в роботі [41] було запропоновано, що подія має показувати «спалахові», швидкі і дрібномасштабні топологічні зміни, пов'язані з високою енергією, щоб бути класифікованою як БЕ.

Отримані в нашій роботі світлові криві досліджуваної БЕ показують, що ми спостерігали дві фази іiї еволюції: фазу попереднього нагрівання і спалахову фазу, під час яких відбувалося поступове та імпульсне виділення енергії. Фазу охолодження спостерігати не вдалося, тому що закінчився 20-хв інтервал спостережень.

\section{ЗМІНИ ХРОМОСФЕРНИХ ПРОМЕНЕВИХ ШВИДКОСТЕЙ}

Для вивчення особливостей руху хромосферної речовини в області розвитку бомби Еллермана було використано I-профілі Стокса, отримані з інтервалом, що відповідає відстані на Сонці 160 км. Відомо, що зсуви і асиметрія $\mathrm{H}_{\alpha}$-профілів в основному залежать від змін поля швидкостей з висотою хромосфери, i їх можна добре відтворити швидкостями на цих висотах [3]. У нашій роботі хромосферні променеві швидкості $V_{\text {пр }}$ на рівні утворення ядра лінії $\mathrm{H}_{\alpha}$ розраховувалися за допплерівськими зсувами ядра лінії в отриманих спектрах відносно його положення в лабораторному спектрі з використанням прилеглих телуричних ліній. При цьому враховувалися всі необхідні поправки: за обертання Землі навколо своєї осі і навколо Сонця, обертання Сонця і гравітаційне зміщення. Похибка визначення $V_{\text {пр }}$ дорівнювала $\pm 0.3 \mathrm{\kappa m} / \mathrm{c}$.

На рис. 6 приведено часові зміни хромосферної променевої швидкості над областю розвитку бомби Еллермана: над її централь- 


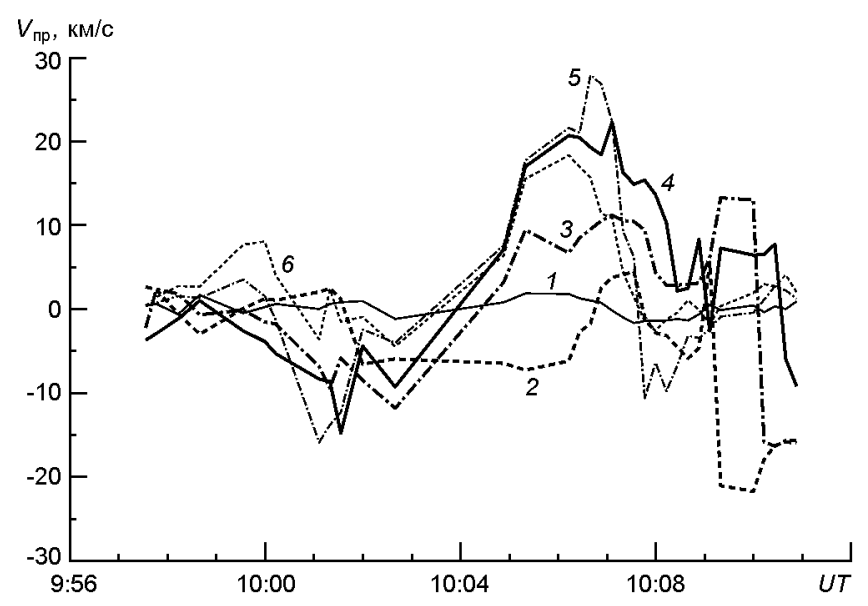

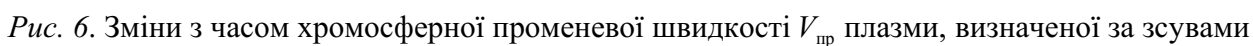
ядра лінії $\mathrm{H}_{\alpha}$ : над центральною частиною БЕ (крива 4), на відстанях \pm 0.67 Мм (криві 3,5 ) та \pm 1.33 Мм (криві 2, б) від неї; крива 1 - променева швидкість на ділянці L2. Негативні значення променевої швидкості відповідають руху у напрямку до спостерігача

ною частиною (крива 4), на відстанях \pm 0.67 Мм від неї (криві 3,5$)$ та \pm 1.33 Мм від неї (криві 2, б). Криві 2 і 6 відносяться до країв БЕ. Криву 1 приведено для порівняння, вона показує розподіл променевої швидкості на ділянці L2 активної області. Під час наших спостережень на цій ділянці без активних утворень і поза областю магнітних потоків значення $V_{\text {пр }}$ зазнавали невеликих коливань поблизу нуля, у межах $\pm 2 \mathrm{KM} / \mathrm{c}$.

На спектрах, отриманих у різні моменти спостережень (рис. 2), видно, що над областю БЕ розвивалися $\mathrm{H}_{\alpha}$-викиди, тому розподіл швидкостей на рівні утворення ядра лінії $\mathrm{H}_{\alpha}$ в основному було зумовлено швидкістю і напрямком руху хромосферної речовини у цих викидах.

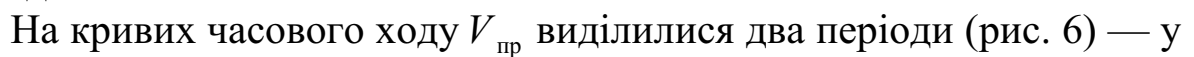
першій половині спостережень хромосферна речовина в основному рухалася вгору, а в другій половині спостережень переважав рух речовини вниз. Нагадаємо, що на світлових кривих БЕ (рис. 5) у першій половині спостережень відбулося зменшення інтенсивності в синьому крилі лінії $\mathrm{H}_{\alpha}$, а у другій половині спостережень - у червоному крилі, що відповідало часу, коли над областю БЕ спостерігалися хромосферні викиди.

Крива 4 показує, що на початку спостережень протягом 1.5 хв відбувалися коливання швидкості від -4 до +1 км/с. 3 моменту $9^{h} 58^{m} 30^{s}$ UT близько 6 хв у цій області спостерігався підйом речовини, причому збільшення швидкості висхідного руху за цей період мало два максимуми: $V_{\text {пр }}=-14.8 \mathrm{\kappa м} / \mathrm{c} \mathrm{о} 10^{h} 01^{m} 20^{s} \mathrm{UT}$ i $V_{\text {пр }}=-9.2 \mathrm{\kappa м} / \mathrm{c}-$ через $75 \mathrm{c}$. Потім швидкість руху речовини вгору стала зменшуватися, о $10^{h} 04^{m} 15^{s}$ UT рух вгору змінився рухом вниз, і майже до кінця спостережень, близько 7.5 хв, спостерігалося опускання хромосферної речо- 
вини. При цьому протягом приблизно 2.5 хв відбулося різке збільшення швидкості від 0 до 20.7 км/с. Через 1 хв променева швидкість в цьому місці досягла максимального значення $22.3 \mathrm{kм} / \mathrm{c}$ і почала поступово зменшуватися, проте зменшення швидкості відбувалося нерівномірно, а носило коливний характер. Близько $10^{h} 11^{m}$ UT хромосферна речовина рухалася зі швидкістю $V_{\text {пр }}=7.8$ км/с. Потім протягом 15 с швидкість вниз зменшилася до нуля, і рух вниз змінився рухом вгору, при цьому швидкість збільшилася до -9.2 км/с, тобто над центральною частиною БЕ з'явився висхідний потік хромосферної речовини.

Розглянемо закономірності змін $V_{\text {пр }} 3$ часом на відстані $\pm 0.67 \mathrm{Mм}$ від центральної області БЕ (криві 3 і 5). Крива 3 показує, що перші 2 хв 15 с спостережень на відстані -0.67 Мм зміни променевої швидкості не перевищували \pm 2 км/с. Період підйому хромосферної речовини, як і на кривій 4, складався 3 двох максимумів і тривав близько 6 хв, але розпочався і закінчився на 40 с пізніше. Перший максимум $\left(V_{\text {пр }}=-9.4\right.$ км/с) спостерігався на 15 с раніше, а другий $\left(V_{\text {пр }}=-11.8\right.$ км/c) - одночасно з максимумом на кривій 4. Близько $10^{h} 04^{m} 40^{s} \mathrm{UT}$ напрямок руху змінився, і приблизно 6 хв в цій області відбувалося опускання речовини з $V_{\text {пр }}$, яка змінювалася від 11.2 до 2.8 км/с. Наприкінці спостережень, о $10^{h} 10^{m} 32^{s} \mathrm{UT}$, речовина в цьому місці опускалася зі швидкістю $13.3 \mathrm{\kappa м} / \mathrm{c}$, потім протягом 15 с швидкість різко зменшилася, рух вниз змінився рухом вгору зі швидкістю до $V_{\text {пр }}=-16.3 \mathrm{\kappa м} / \mathrm{c}$. Така різка зміна напрямку руху і значення швидкості свідчить про наявність в цьому місці поруч із низхідним потоком з швидкістю до 13 км/с висхідного потоку з швидкістю -16 км/с. У центральній частині профілів лінії $\mathrm{H}_{\alpha}$ для БЕ видно два компоненти, ядра яких зсунуті у протилежні боки від ядра профілю лінії для ділянки L2 (ці профілі будуть розглядатися у другій частині роботи, де буде детально вивчатися утворення і розвиток $\mathrm{H}_{\alpha}$-викидів на досліджуваній ділянці). На спектрах, отриманих в цей час, викиди видно як в синьому, так і у червоному крилі. Зауважимо, що за 15 с до цього спостерігався найвищий максимум інтенсивності в синьому крилі лінії $\mathrm{H}_{\alpha}-$ відбулося магнітне перез'єднання (рис. 5), в результаті якого підвищилася яскравість БЕ і утворився новий викид, помітний в синьому крилі і ядрі лінії $\mathrm{H}_{\alpha}$.

На рис. 6 видно, що на відстані +0.67 Мм (крива 5) швидкості руху речовини, спрямовані до спостерігача і від нього, мали максимальні значення. На початку спостережень протягом 3 хв відбувалося опускання речовини 3 невеликою швидкістю до 3.5 км/с. Період руху речовини вгору почався пізніше на 40 с у порівнянні з центральною частиною (крива 4) і тривав близько 4 хв. Крива 5 в цей період мала два максимуми: $V_{\text {пр }}=-15.8 \mathrm{\kappa m} / \mathrm{c} \mathrm{o} 10^{h} 00^{m} 50^{s} \mathrm{UT}$ i $V_{\text {пр }}=-4 \mathrm{\kappa м} / \mathrm{c}-$ через 100 с. Зауважимо, що другий максимум збігався за часом з другим максимумом на кривих 3 i 4, також в цей час спостерігався максимум на всіх світлових кривих БЕ. Ймовірно, в цей час відбулося магнітне 
перез'єднання, в результаті якого утворилися потоки плазми, які йшли вгору від місця перез'єднання і викликали збільшення швидкості руху хромосферної речовини. Зміна знаку швидкості сталася близько $10^{h} 03^{m} 30^{s} \mathrm{UT}$, і протягом 5 хв у цій області хромосферна речовина опускалася, поступово прискорюючись. У цей період максимальне значення $V_{\text {пр }}=28 \mathrm{\kappa м} / \mathrm{c}$ було досягнуте о $10^{h} 07^{m} \mathrm{UT}$. Потім протягом 1 хв величина променевої швидкості різко змінилася до $-10.6 \mathrm{kм} / \mathrm{c}$ (близько $10^{h} 08^{m} \mathrm{UT}$ значення швидкості перетнули нуль), тобто поруч перебували потоки плазми з різноспрямованим рухом. Зауважимо, що за 30 с до цього спостерігався перший максимум (в імпульсній фазі) на всіх світлових кривих БЕ. В результаті перез'єднання утворився ще один викид 3 висхідним рухом плазми. Наприкінці спостережень близько 3 хв в цьому місці відбувався підйом речовини зі швидкістю, яка поступово зменшувалась.

На відстані \pm 1.33 Мм (криві 2 і б) від центральної області БЕ у зміні $V_{\text {пр }} 3$ часом так само виділяються періоди, під час яких спостерігалися як висхідні, так і низхідні потоки хромосферної речовини, однак з меншими швидкостями. 3 вигляду кривої 2 видно, що в цьому місці, над нижньою межею БЕ (див. спектри на рис. 2), в основному відбувався підйом хромосферної речовини. Протягом перших 4.5 хв спостережень, до моменту $10^{h} 01^{m} 30^{s} \mathrm{UT}$, значення $V_{\text {пр }}$ зазнавали коливань від -3 км/с до +2.5 км/с. Потім протягом 6 хв речовина рухалася вгору з середньою швидкістю приблизно 6 км/с, на відповідних спектрах видно викид у синьому крилі лінії $\mathrm{H}_{\alpha}$. За останні 4.5 хв спостережень рух речовини ще двічі змінював напрямок - о $10^{h} 07^{m} \mathrm{UT}$ i через 45 с; при цьому значення швидкості коливалися від 4.5 км/с до $-6 \mathrm{kм} / \mathrm{c}$. Близько $10^{h} 09^{m} 40^{s}$ UT протягом 45 с променева швидкість різко змінилася від 5.6 до -21.7 км/с, тобто в цей час в цьому місці перебували два протилежно спрямованих потоки хромосферної речовини. За 15 с до різкої зміни швидкості спостерігався максимум інтенсивності в синьому крилі. На спектрах викиди видно в обох крилах, проте за 45 с викид у червоному крилі зменшився, а в синьому викид збільшився - відбувся зсув ядра профілю до синього краю - швидкість низхідного руху зменшилась, а висхідного - збільшилась.

Крива 6 показує, що в цій області протягом наших спостережень переважно відбувався рух речовини вниз. На початку спостережень протягом 3.5 хв зі швидкістю до 8 км/с (на спектрах в червоному крилі видно викид) і з моменту $10^{h} 03^{m} 50^{s}$ UT протягом 4.5 хв 3 максимальною швидкістю 18.4 км/с, яку було досягнуто о $10^{h} 06^{m} 17^{s} \mathrm{UT}$. Останні 3.5 хв спостережень значення $V_{\text {пр }}$ зазнавали коливань від -2.6 до $4.1 \mathrm{\kappa м} / \mathrm{c} з$ інтервалом близько 1 хв.

Отримані нами часові зміни променевої швидкості руху хромосферної речовини над областю розвитку БЕ на рівні утворення ядра лінії $\mathrm{H}_{\alpha}$ вказують на те, що розподіл швидкостей у цій області був зумовлений розвитком хромосферних викидів. На початку спостережень протягом приблизно 2 хв над всією областю БЕ відбувалися 
коливання променевої швидкості у межах \pm 3 км/с, що не набагато перевищували коливання величини $V_{\text {пр }}$ на ділянці L2 (рис. 6). Потім сформувався викид над центральною частиною БЕ, на спектрах його видно в короткохвильовому крилі і у ядрі лінії $\mathrm{H}_{\alpha}$, вказуючи на те, що речовина викиду рухалася по магнітній петлі вгору (див. рис. 2 і криву 4 на рис. 6). До моменту $10^{h} 01^{m} 06^{s}$ UT сформувався ще один викид, вони зайняли всю площу над БЕ. Це видно на спектрі 2 (рис. 2) і на рис. 6: висхідний рух стали показувати і криві 3 i 5. Максимальна швидкість руху вгору досягла $-12 \ldots-16$ км/с над різними частинами БЕ, потім вона почала зменшуватися i, як показує рис. 6, рух вгору змінився рухом вниз, при цьому максимальна швидкість руху була удвічі більшою - до $22 . . .30$ км/с. На спектрі 3 (рис. 2) викиди видно вже в довгохвильовому крилі. Це свідчить про те, що речовина викидів почала рухатися вниз уздовж магнітних петель по тих же траєкторіях, тобто над БЕ спостерігалися зворотні викиди. Таке ж співвідношення змін швидкостей у викиді, що супроводжував БЕ, було отримано в роботі [42] - швидкість висхідного руху досягла $20 \mathrm{kм} / \mathrm{c}$, а низхідного - $40 \mathrm{kм} / \mathrm{c}$. Викид і БЕ спостерігалися в лініях $\mathrm{H}_{\alpha}$ i Ca II $\lambda 854.2$ нм.

Часові зміни $V_{\text {пр }}$ над протилежними межами області розвитку БЕ (криві 2 і 6) показують, що з одного боку від БЕ переважно спостерігався рух хромосферної речовини вгору (крива 2), а з іншого боку рух вниз (крива б). Ймовірно, це вказує на те, що над областю БЕ утворився петельний викид - плазма рухалася з однієї основи до іншої.

Звернемо увагу на те, що один з викидів мав ознаки вихрових рухів плазми - на спектрі 3 (рис. 2) добре видно темну похилу деталь, що перетинає ядро і червоне крило лінії $\mathrm{H}_{\alpha}$.

Було досліджено також, як змінювалися за час наших спостережень променеві швидкості та напрямок руху хромосферної речовини на рівні утворення ядра лінії $\mathrm{H}_{\alpha}$ навколо бомби Еллермана. На рис. 7 представлено зміни $V_{\text {пр }}$ уздовж ділянки АО, вирізаної щілиною спектрографа, для 10 різних моментів спостережень. Криві змін $V_{\text {пр }}$, побудовані для цих моментів, були об'єднані у пари таким чином, що за час між цими кривими зберігався вид розподілу променевих швидкостей.

Крива 1 стосується початку спостережень. Видно, що в цей час по всій площі ділянки відбувалися коливання швидкості, які не перевищували \pm 3 км/с, вони мало відрізнялися від значень швидкості на ділянці без активних утворень L2. БЕ перебувала в області, де допплерівські швидкості змінювали знак, і це узгоджується з даними робіт $[39,44]$. Через 4 хв (крива 2) на частині ділянки розподіл швидкості не змінився, а над БЕ і їі найближчими околицями відбувався підйом хромосферної речовини - розвинулися викиди, речовина яких рухалася вгору зі швидкістю до 14 км/с. На наступних кривих 3 і 4 видно, що на ділянці спостерігалися як висхідні, так і низхідні потоки речовини з максимальними швидкостями до -11 і 30 км/с відповідно. 


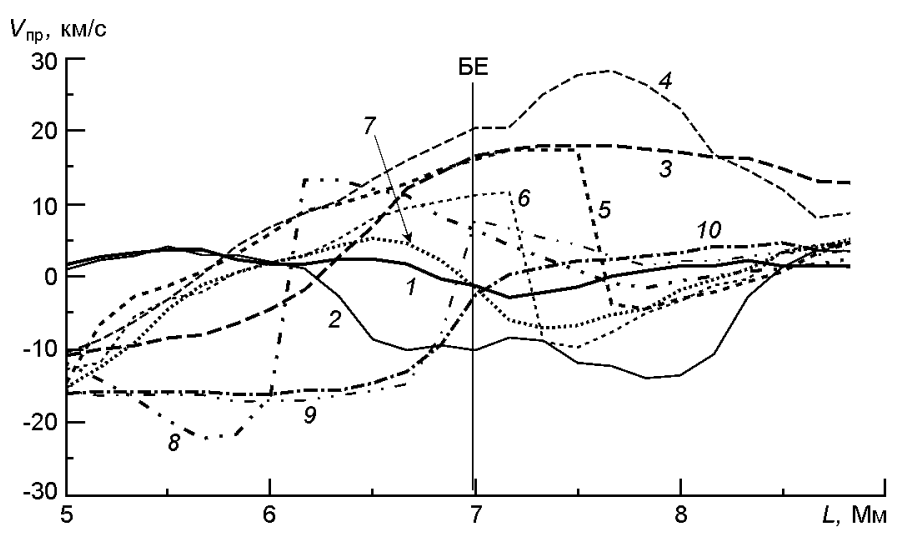

Рис. 7. Зміни хромосферної променевої швидкості уздовж ділянки АО, вирізаної щілиною спектрографа, для різних моментів спостережень: $9^{h} 57^{m} 18^{s}, 10^{h} 01^{m} 06^{s}, 10^{h} 07^{m}, 10^{h} 08^{m} 11^{s}$, $10^{h} 08^{m} 39^{s}, 10^{h} 08^{m} 52^{s}, 10^{h} 10^{m} 18^{s}, 10^{h} 11^{m} 01^{s}, 10^{h} 11^{m} 15^{s}$ UT (криві $1 \ldots 10$ відповідно). Вертикальна лінія - положення бомби Еллермана. Позитивні значення променевої швидкості відповідають руху у напрямку від спостерігача

В цей час речовина викидів почала рухатися вниз зі швидкістю, набагато більшою, ніж вона підіймалась. Це узгоджується з даними, отриманими в роботі [42]. Криві 5 і 6 , а також 8 і 9 показують, що в деякі моменти на досліджуваній ділянці в невеликій області, близько $160 \ldots 250$ км (1...1.5 пікселя на спектрі), відбувалася різка зміна швидкості і напрямку руху хромосферної речовини - могли поруч перебувати два протилежно спрямованих потоки. На кривих 5 і 6 позитивні швидкості змінилися на негативні, тобто рух вниз зі швидкістю до $12 \ldots 18 \mathrm{\kappa m} / \mathrm{c}$ змінився на рух вгору зі швидкостями до $-4 . . .-10$ км/с. Криві 8 і 9 показують, що з іншого боку від БЕ потік вгору зі швидкостями до $-17 \ldots-22$ км/с перебував поруч з потоком вниз зі швидкостями до $8 . .14$ км/с. Крива 10, отримана для одного 3 останніх моментів спостережень, показує, що на ділянці з одного боку від БЕ спостерігався висхідний потік речовини зі швидкістю до -16 км/c, а з іншого боку від БЕ - рух вниз з невеликою швидкістю до 4 км/с. Це вказує на те, що бомба Еллермана розвивалася під петельним викидом.

На спектрах видно (рис. 2), що вигляд ділянки сильно змінювався від одного спостереження до іншого - розвивалася БЕ, з'являлися нові викиди, вони розщеплювалися на фрагменти, хромосферна речовина в них рухалася з різною швидкістю як вгору, так і вниз. Це було наслідком того, що на ділянці, яку ми досліджуємо, виходив новий змієподібний магнітний потік і в результаті взаємодії його петель 3 уже наявним магнітним полем, або між магнітними петлями самого потоку відбувалися магнітні перез'єднання. Наш висновок узгоджується 3 висновком роботи [42], згідно з яким БЕ і пов'язаний $з$ нею викид є реакцією атмосфери на процес магнітного перез'єднання, який був викликаний появою дрібномасштабного потоку і відбувався 
у нижній хромосфері.

\section{ВИСНОВКИ}

У даній роботі ми продовжуємо вивчати динаміку атмосфери активної області NOAA 11024 на основі спектрополяриметричного матеріалу, отриманого С. В. Хоменко на франко-італійському телескопі THEMIS з високою просторовою $\left(\sim 1^{\prime \prime}\right)$ і часовою ( $>$ с) роздільними здатностями. У день наших спостережень, 4 липня 2009 р., область була на стадії різкого зростання активності. Досліджувана ділянка АО перебувала в області одного з магнітних потоків, що в цей час виходив. Це була серія невеликих ділянок зі змішаною полярністю - так зване серпантинове магнітне поле. За час наших спостережень на ньому розвинулися бомба Еллермана і різного виду $\mathrm{H}_{\alpha}$-викиди (surges). На всіх спектрах викиди були видні у поглинанні як в довгохвильовому, так і в короткохвильовому крилі лінії $\mathrm{H}_{\alpha}$.

У першій частині роботи детально вивчено особливості утворення і розвитку бомби Еллермана під час наших спостережень.

Отримано, що БЕ утворилася у місці підвищеної яскравості. Форма профілів лінії $\mathrm{H}_{\alpha}$ була дуже різноманітною. Профілі, що стосуються різних стадій розвитку БЕ, в основному складалися з кількох компонентів, були асиметричними по протяжності та інтенсивності крил 3 надлишком емісії в короткохвильовому крилі. Максимальне збільшення інтенсивності емісійного компонента, у порівнянні з профілем для ділянки АО без активних утворень, на 73 \% у короткохвильовому крилі і на 35 \% у довгохвильовому крилі, відбулося на відстані \pm 0.16 нм від ядра лінії $\mathrm{H}_{\alpha}$. За час наших спостережень положення максимуму інтенсивності емісії як в синьому, так і в червоному крилі кілька разів змінювалося, що є свідченням зміни конфігурації магнітного поля в області БЕ.

На отриманих нами часових кривих зміни інтенсивності у крилах лінії $\mathrm{H}_{\alpha}$, на відстані $\pm 0.1 \mathrm{i} \pm 0.16$ нм від її центра, можна виділити два періоди. Перший період, протягом якого інтенсивність змінювалася мало, тривав близько 8 хв. Другий період тривалістю близько 6 хв, протягом якого яскравість БЕ збільшувалася, складався з п'яти піків 3 інтервалом близько 1 хв. Світлові криві показують, що ми спостерігали дві фази еволюції БЕ: фазу попереднього нагрівання і спалахову фазу, під час яких відбувалося поступове та імпульсне виділення енергіï.

Розмір області, яку займала БЕ уздовж щілини спектрографа, змінювався 3 часом: на початку спостережень він становив близько $2.3^{\prime \prime} . .2 .9^{\prime \prime}$, а в кінці спостережень - $1.5^{\prime \prime}$.

Отримані нами часові зміни променевої швидкості руху хромосферної речовини над областю розвитку БЕ на рівні утворення ядра лінії $\mathrm{H}_{\alpha}$ вказують на те, що розподіл швидкостей в цій області був зумовлений в основному розвитком хромосферних викидів. Під час 
наших спостережень на ділянці без активних утворень значення $V_{\text {пр }}$ зазнавали невеликі коливання близько нуля, у межах \pm 2 км/с.

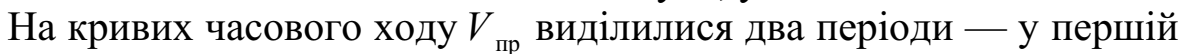
половині спостережень хромосферна речовина рухалася переважно вгору, а у другій половині спостережень переважав рух речовини вниз.

Над областю розвитку БЕ спостерігалися різного виду $\mathrm{H}_{\alpha}$-викиди. Максимальна швидкість руху вгору у зворотних викидах досягала $-12 \ldots-16$ км/с, опускалася хромосферна речовина уздовж магнітних петель по тих же траєкторіях зі швидкістю, удвічі більшою, - до $22 . .30$ км/с. У петельному викиді максимальна швидкість висхідного руху з одного боку петлі становила $-7 \mathrm{~km} / \mathrm{c}$, а низхідного, 3 іншого боку петлі, досягала 18 км/с. Один з викидів мав ознаки вихрових рухів плазми, про що свідчать похилі темні смуги на спектрах.

Для досліджень ми обрали ділянку $\mathrm{AO}$ з дуже високою активністю. Вигляд іï спектрів сильно змінювався від одного спостереження до іншого - розвивалася БЕ, з'являлися нові $\mathrm{H}_{\alpha}$-викиди, вони розщеплювалися на фрагменти, хромосферна речовина у них рухалася з різною швидкістю як вгору, так і вниз. Ймовірно, це було викликано послідовними магнітними перез'єднаннями, які відбувалися в результаті виходу нового змієподібного магнітного потоку і взаємодією його петель з уже наявним магнітним полем, або між магнітними петлями самого потоку.

Автор висловлює подяку Є. В. Хоменко і Р. І. Костику за матеріали спостережень на франко-італійському 90-см вакуумному телескопі THEMIS Інституту астрофізики на Канарських островах і програми 3 їхньої обробки.

1. Пикельнер С. Б. Природа точечных источников линейчатой, непрерывной и рентгеновской эмиссии на Солнце. Астрон. Журн. 1974. 51. № 2. С. 3-22.

2. Северный А. Б. Исследование тонкой структуры эмиссии активных образований и нестационарных процессов на Солнце. Изв. КрАО. 1957. 17. С. 129-161.

3. Bello González N., Danilovic S., Kneer F. On the structure and dynamics of Ellerman bombs. Detailed study of three events and modelling of $\mathrm{H \alpha}$. Astron. and Astrophys. 2013. 557, id. A102. 16 p.

4. Berlicki A., Heinzel P. Observations and NLTE modeling of Ellerman bombs. Astron. and Astrophys. 2014. 567. P. 1-10.

5. Borovik A.V., Myachin D. Yu. The spotless flare of March 16, 1981. I. Preflare activations of the chromospheric fine structure. Solar Phys. 2002. 205, Issue 1. P. $105-116$.

6. Chae J., Qiu J., Wang H., Goode P. R. Extreme-ultraviolet jets and H $\alpha$ surges in solar microflares. Astrophys. J. 1999. 513, Issue 1. L75-L78.

7. Ding M. D., Henoux J.-C., Fang C. Line profiles in moustaches produced by an impacting energetic particle beam. Astron. and Astrophys. 1998. 332. P. 761-766.

8. Dominguez S. V., L. van Driel-Gesztelyi, Bellot Rubio L. R. Granular-Scale Elementary Flux Emergence Episodes in a Solar Active Region. Solar Phys. 2012. 278, Issue 1. P. 99-120. 
9. Engell A. J., Siarkowski M., Gryciuk M., et al. Flares and their underlying magnetic complexity. Astrophys. J. 2011. 726. P. 12-20.

10. Fang C., Tang Y. H., Xu Z., et al. Spectral analysis of Ellerman bombs. Astrophys. J. 2006. 643. P. 1325-1336.

11. Georgoulis M. K., Rust D. M., Bernasconi P. N., et al. Statistics, morphology, and energetics of Ellerman bomb. Astrophys. J. 2002. 575. P. 506-528.

12. Guglielmino S. L., Bellot Rubio L. R., Zuccarello F., et al. Multiwavelength observations of small-scale reconnection events triggered by magnetic flux emergence in the solar atmosphere. Astrophys. J. 2010. 724. P. 1083-1098.

13. Hansteen V. H., Ortiz A., Archontis V., et al. Ellerman bombs and UV bursts: transient events in chromospheric current sheets. Astron. and Astrophys. 2019. 626. id.A33. $10 \mathrm{p}$.

14. Hashimoto Yu., Kitai R., Ichimoto K., et al. Internal fine structure of Ellerman bombs. Publ. Astron. Soc. Japan. 2010. 62. P. 879-891.

15. Herlender M., Berlicki A. Spectrophotometric analysis of an Ellerman bomb. Cent. Eur. Astrophys. Bull. 2010. 34. P. 65-72.

16. Herlender M., Berlicki A. Multi-wavelength analysis of Ellerman bomb light curves. Cent. Eur. Astrophys. Bull. 2011. 35. P. 181-186.

17. Huang Zhenghua, Mou Chaozhou, Fu Hui, et al. A magnetic reconnection event in the solar atmosphere driven by relaxation of a twisted arch filament system. Astrophys. $J$. Lett. 2018. 853, Issue 2. article id. L26. 8 pp.

18. Jess D. B., Mathioudakis M., Browning P. K., et al. Microflare activity driven by forced magnetic reconnection. Astrophys. J. Lett. 2010. 712. L111-L115.

19. Kitai R. On the mass motions and the atmospheric states of moustaches. Solar Phys. 1983. 87. P. 135-154.

20. Kondrashova N. N. Spectropolarimetric ivestigation of an Ellerman bomb: 1. Observations. Kinematics Phys. Celestial Bodies. 2016. 32, issue 1. P. 13-22.

21. Kondrashova N. N., Pasechnik M. N., Chornogor S. N., et al. Atmosphere dynamics of the active region NOAA 11024. Solar Phys. 2013. 284, Issue 2. P. 499-513.

22. Li Z., Fang C., Guo Y., et al. Diagnostics of Ellerman bombs with high-resolution spectral data. Res. Astron. and Astrophys. 2015. 15. Issue 9. article id. 1513.

23. Madjarska M. S., Doyle J. G., de Pontieu B. Explosive events associated with a surge. Astrophys. J. 2009. 701. P. 253-259.

24. Matsumoto T., Kitai R., Shibata K., et al. Height dependence of gas flows in an Ellerman bomb. Publ. Astron. Soc. Jap. 2008. 60. P. 95-102.

25. Matsumoto T., Kitai R., Shibata K., et al. Cooperative observation of Ellerman bombs between the Solar Optical Telescope aboard Hinode and Hida/Domeless Solar Telescope. Publ. Astron. Soc. Jap. 2008. 60. P. 577-585.

26. Nelson C. J., Doyle J. G., Erdelyi R., et al. Statistical analysis of small Ellerman bomb events. Solar Phys. 2013. 283, Issue 2. P. 307-323.

27. Nelson C. J., Scullion E. M., Doyle J. G. et al. Small-scale structuring of Ellerman bombs at the solar limb. Astrophys. J. 2015. 798, Issue 1. P. 1-9.

28. Ortiz A., Hansteen V. H., Nobrega-Siverio D., et al. Ellerman bombs and UV bursts: reconnection at different atmospheric layers. Astron. and Astrophys. 2020. 633, id. A58. 19 p.

29. Pariat E., Aulanier G., Schmieder B., et al. Resistive emergence of undulatory flux tubes. Astrophys. J. 2004. 614. P. 1099-1112.

30. Pariat E., Schmieder B., Berlicki A., et al. Spectrophotometric analysis of Ellerman bombs in the $\mathrm{Ca}$ II, $\mathrm{H} \alpha$, and UV range. Astron. and Astrophys. 2007. 473. P. $279-289$. 
31. Pasechnik M. N. Plasma motions in the solar loop of emerging magnetic flux. Kinematics Phys. Celestial Bodies. 2014. 30, issue 4. P. 161-172.

32. Pasechnik M. N. Spectral study of a pair of Ellerman bombs. Kinematics Phys. Celestial Bodies. 2016. 32, Issue 3. P .55-69.

33. Pasechnik M. N. Spectral study of Ellerman bombs. Photosphere. Kinematics Phys. Celestial Bodies. 2018. 34, Issue 2. P.68-81.

34. Pasechnik M. N. Motion of photospheric matter within the active region site with two Ellerman bombs. Kinematics Phys. Celestial Bodies. 2019. 35, Issue 2. P. 55-69.

35. Qiu J., Ding M.D., Wang H., et al. Ultraviolet and H $\alpha$ emission in Ellerman bombs. Astrophys. J. 2000. 544. LI 57-L161.

36. Reid A., Mathioudakis M., Scullion E., et al. Ellerman bombs with jets: cause and effect. Astrophys. J. 2015. 805. Issue 1. article id. 649 p.

37. Socas-Navarro H., Martínez Pillet V., Elmore D., et al. Spectro-polarimetric observations and non-LTE modeling of Ellerman bombs. Solar Phys. 2006. 235, Issue 1-2. P. $75-86$.

38. Valori G., Green L. M., Demouli P., et al. Nonlinear force-free extrapolation of emerging flux with a global twist and serpantine fine structures. Solar Phys. 2012. 278, Issue 1. P. 73-97.

39. Vissers Gregal J. M., Rouppe van der Voort, Luc H. M ., et al Ellerman bombs at high resolution. II. Triggering, visibility, and effect on upper atmosphere. Astrophys. J. 2013. 774. P. 1-14.

40. Watanabe H., Kitai R., Okamoto K., et al. Spectropolarimetric observation of an emerging flux region: triggering mechanisms of Ellerman bombs. Astrophys. $J$. 2008. 684. P. 736-746.

41. Watanabe H., Vissers G., Kitai R., et al. Ellerman bombs at high resolution: 1. Morphological evidence for photospheric reconnection. Astrophys. J. 2011. 736, Issue 1. P. $71-83$.

42. Yang H., Chae J., Lim E.-K., et al. Velocities and temperatures of an Ellerman bomb and its associated features. Solar Phys. 2013. 288, Issue 1. P. 39-53.

43. Young P. R., Tian H., Peter H., et al. Solar ultraviolet bursts. Space Science Reviews. 2018. 214, Issue 8. article id. 120. 39 p.

44. Zachariadis Th. G., Alissandrakis C. E., Banos G. Observations of Ellerman bombs in Ha. Solar Phys. 1987. 108, Issue 2. P. 227-236.

45. Zirin H. The solar atmosphere. 1966. Blaisdell Publ. Co., Massachusetts, U.S.A.

\section{REFERENCES}

1. Pikel'ner S. B. (1974) The nature of point-sources of lined, continuous and X-ray emission on the Sun. Astron. Zh. 51(2). 233-242.

2. Severnyi A. B. (1957) Investigating the fine structure of the emission of active formations and nonstationary processes on the Sun. Izv. Krym. Astrofiz. Obs. 17. $129-161$.

3. Bello González N., Danilovic S., Kneer F. (2013) On the structure and dynamics of Ellerman bombs. Detailed study of three events and modelling of Ha. Astron. and Astrophys. 557, id. A102. 16.

4. Berlicki A., Heinzel P. (2014) Observations and NLTE modeling of Ellerman bombs. Astron. and Astrophys. 567. 1-10.

5. Borovik A. V., Myachin D. Yu. (2002) The spotless flare of March 16, 1981. I. Preflare activations of the chromospheric fine structure. Solar Phys. 205(1). 105-116. 
6. Chae J., Qiu J., Wang H., Goode P. R. (1999) Extreme-ultraviolet jets and Ha surges in solar microflares. Astrophys. J. 513(1). L75-L78.

7. Ding M. D., Henoux J.-C., Fang C. (1998) Line profiles in moustaches produced by an impacting energetic particle beam. Astron. and Astrophys. 332. 761—766.

8. Dominguez S. V., L. van Driel-Gesztelyi, Bellot Rubio L. R. (2012) Granular-scale elementary flux emergence episodes in a solar active region. Solar Phys. 278(1). $99-120$.

9. Engell A. J., Siarkowski M., Gryciuk M., et al. (2011) Flares and their underlying magnetic complexity. Astrophys. J. 726. 12-20.

10. Fang C., Tang Y. H., Xu Z., et al. (2006) Spectral analysis of Ellerman bombs. Astrophys. J. 643. 1325-1336.

11. Georgoulis M. K., Rust D. M., Bernasconi P. N., et al. (2002) Statistics, Morphology, and Energetics of Ellerman Bomb. Astrophys. J. 575. 506-528.

12. Guglielmino S. L., Bellot Rubio L. R., Zuccarello F., et al. (2010) Multiwavelength observations of small-scale reconnection events triggered by magnetic flux emergence in the solar atmosphere. Astrophys. J. 724. 1083-1098.

13. Hansteen V. H., Ortiz A., Archontis V., et al. (2019) Ellerman bombs and UV bursts: transient events in chromospheric current sheets. Astron. and Astrophys. 626. id.A33. 10.

14. Hashimoto Yu., Kitai R., Ichimoto K., et al. (2010) Internal fine structure of Ellerman bombs. Publ. Astron. Soc. Japan. 62. 879-891.

15. Herlender M., Berlicki A. (2010) Spectrophotometric analysis of an Ellerman bomb. Cent. Eur. Astrophys. Bull. 34. 65-72.

16. Herlender M., Berlicki A. (2011) Multi-wavelength analysis of Ellerman bomb light curves. Cent. Eur. Astrophys. Bull. 35. 181-186.

17. Huang Zhenghua, Mou Chaozhou, Fu Hui, et al. (2018) A magnetic reconnection event in the solar atmosphere driven by relaxation of a twisted arch filament system. Astrophys. J. Lett. 853(2). id. L26. 8.

18. Jess D. B., Mathioudakis M., Browning P. K ., et al. (2010) Microflare activity driven by forced magnetic reconnection. Astrophys. J. Lett. 712. L111-L115.

19. Kitai R. (1983) On the mass motions and the atmospheric states of moustaches. Solar Phys. 87. 135-154.

20. Kondrashova N. N. (2016) Spectropolarimetric ivestigation of an Ellerman bomb: 1. Observations. Kinematics Phys. Celestial Bodies. 32(1). 13-22.

21. Kondrashova N. N., Pasechnik M. N., Chornogor S. N., et al. (2013) Atmosphere dynamics of the active region NOAA 11024. Solar Phys. 284(2). 499-513.

22. Li Z., Fang C., Guo Y., et al. (2015) Diagnostics of Ellerman bombs with high-resolution spectral data. Res. Astron. and Astrophys. 15(9). id. 1513.

23. Madjarska M. S., Doyle J. G., de Pontieu B. (2009) Explosive events associated with a surge. Astrophys. J. 701. 253-259.

24. Matsumoto T., Kitai R., Shibata K., et al. (2008) Height dependence of gas flows in an Ellerman bomb. Publ. Astron. Soc. Jap. 60. 95-102.

25. Matsumoto T., Kitai R., Shibata K., et al. (2008) Cooperative observation of Ellerman bombs between the Solar Optical Telescope aboard Hinode and Hida/Domeless Solar Telescope. Publ. Astron. Soc. Jap. 60. 577-585.

26. Nelson C. J., Doyle J. G., Erdelyi R., et al. (2013) Statistical analysis of small Ellerman bomb events. Solar Phys. 283(2). 307-323.

27. Nelson C. J., Scullion E. M., Doyle J. G., et al. (2015) Small-scale Structuring of Ellerman bombs at the Solar Limb. Astrophys. J. 798(1). 1-9. 
28. Ortiz A., Hansteen V. H., Nobrega-Siverio D., et al. (2020) Ellerman bombs and UV bursts: reconnection at different atmospheric layers. Astron. and Astrophys. 633, id. A58. 19.

29. Pariat E., Aulanier G., Schmieder B., et al. ( 2004) Resistive emergence of undulatory flux tubes. Astrophys. J. 614. 1099-1112.

30. Pariat E., Schmieder B., Berlicki A., et al. (2007) Spectrophotometric analysis of

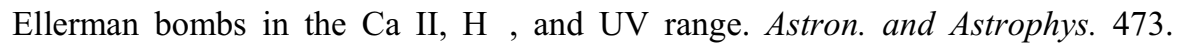
$279-289$.

31. Pasechnik M. N. (2014) Plasma motions in the solar loop of emerging magnetic flux. Kinematics Phys. Celestial Bodies. 30(4). 161-172.

32. Pasechnik M. N. (2016) Spectral study of a pair of Ellerman bombs. Kinematics Phys. Celestial Bodies. 32(3). 55-69.

33. Pasechnik M. N. (2018) Spectral Study of Ellerman Bombs. Photosphere. Kinematics Phys. Celestial Bodies. 34(2). 68-81.

34. Pasechnik M. N. (2019) Motion of photospheric matter within the active region site with two Ellerman Bombs. Kinematics Phys. Celestial Bodies. 35(2). 55-69.

35. Qiu J., Ding M. D., Wang H., et al. (2000) Ultraviolet and H $\alpha$ emission in Ellerman Bombs. Astrophys. J. 544. L157-L161.

36. Reid A., Mathioudakis M., Scullion E., et al. (2015) Ellerman bombs with jets: cause and effect. Astrophys. J. 805(1). id. 64. 9.

37. Socas-Navarro H., Martínez Pillet V., Elmore D., et al. (2006) Spectro-polarimetric observations and non-LTE modeling of Ellerman bombs. Solar Phys. 235(1-2). $75-86$.

38. Valori G., Green L. M., Demouli P., et al. (2012) Nonlinear force-free extrapolation of emerging flux with a global twist and serpantine fine structures. Solar Phys. 278(1). $73-97$.

39. Vissers Gregal J. M., Rouppe van der Voort, Luc H. M., et al. (2013) Ellerman bombs at high resolution. II. Triggering, visibility, and effect on upper atmosphere. Astrophys. J. 774. 1-14.

40. Watanabe H., Kitai R., Okamoto K., et al. (2008) Spectropolarimetric observation of an emerging flux region: triggering mechanisms of Ellerman bombs. Astrophys. J. 684. $736-746$.

41. Watanabe H., Vissers G., Kitai R., et al. (2011) Ellerman bombs at high resolution: 1. Morphological evidence for photospheric reconnection. Astrophys. J. 736(1). $71-83$.

42. Yang H., Chae J., Lim E.-K., et al. (2013) Velocities and temperatures of an Ellerman bomb and its associated features. Solar Phys. 288(1). 39-53.

43. Young P. R., Tian H., Peter H., et al. (2018) Solar ultraviolet bursts. Space Sci. Revs. 214(8). id. 120. 39.

44. Zachariadis Th. G., Alissandrakis C. E., Banos G. (1987) Observations of Ellerman bombs in Ha. Solar Phys. 108(2). 227-236.

45. Zirin H. (1966) The solar atmosphere, Blaisdell Publ. Co., Massachusetts, U.S.A.

\section{М. Н. Пасечник}

Главная астрономическая обсерватория Национальной академии наук Украины, Киев, Украина

\section{СПЕКТРАЛЬНОЕ ИССЛЕДОВАНИЕ УЧАСТКА АКТИВНОЙ ОБЛАСТИ \\ С БОМБОЙ ЭЛЛЕРМАНА И Н \\ ХРОМОСФЕРА. БОМБА ЭЛЛЕРМАНА}


Представлены результаты анализа спектральных наблюдений в линии $\mathrm{H}_{\alpha}$ участка активной области NOAA 11024 , на котором развивались бомба Эллермана и разного вида хромосферные выбросы. Спектральные данные с высоким пространственным и временным разрешением были получены на франко-итальянском солнечном телескопе THEMIS (о. Тенерифе, Испания) 4 июля 2009 года. Время наблюдений 20 мин. В день наблюдений АО находилась на стадии резкого роста активности. Профили линии $\mathrm{H}_{\alpha}$, полученные для разных периодов развития бомбы Эллермана, были очень разнообразными, в основном состояли из нескольких компонентов, были асимметричными с избытком эмиссии в коротковолновом крыле. Максимальное увеличение интенсивности эмиссионного компонента, по сравнению с профилем для участка АО без активных образований, в коротковолновом крыле на 73 \% и в длинноволновом крыле на $35 \%$ произошло на расстоянии \pm 0.16 нм от ядра линии $\mathrm{H}_{\alpha}$. Изменения интенсивности в крыльях линии $\mathrm{H}_{\alpha}$ указывают на то, что во время развития бомбы Эллермана в течение первых 8 мин происходило постепенное, а затем, в течение 6 мин, — импульсное выделение энергии. Период увеличения яркости БЭ состоял из пяти пиков с интервалом около 1 мин. Полученные нами временные изменения лучевой скорости ( $\left.V_{\text {луч}}\right)$ движения хромосферного вещества над областью развития БЭ на уровне образования ядра линии $\mathrm{H}_{\alpha}$ указывают на то, что распределение скоростей в этой области было в основном обусловлено развитием хромосфер-

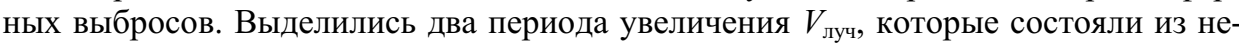
скольких индивидуальных пиков - в первой половине наблюдений хромосферное вещество в основном двигалось вверх, а во второй половине наблюдений преоблада-

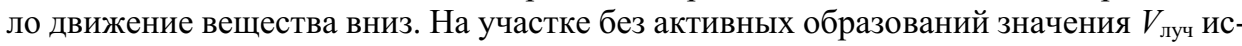
пытывали небольшие колебания в пределах \pm 2 км/с. Над областью развития БЭ наблюдались разного вида $\mathrm{H}_{\alpha}$-выбросы. Максимальная скорость движения вверх в возвратных выбросах достигала $-12 \ldots-16$ км/с, опускалось хромосферное вещество вдоль магнитных петель по тем же траекториям со скоростью, в два раза большей до $22 . .30$ км/с. В петельном выбросе максимальная скорость восходящего движения с одной стороны петли составляла -7 км/c, а нисходящего, с другой стороны петли, - достигала 18 км/с. Один из выбросов имел признаки вихревых движений плазмы, о чем свидетельствуют наклонные темные полосы на спектрах. Особенности изменения интенсивности в крыльях линии $\mathrm{H}_{\alpha}$ и лучевой скорости хромосферного вещества указывают на то, что бомба Эллермана и сопровождающие ее $\mathrm{H}_{\alpha}$-выбросы, которые возникли и развивались на исследуемом нами участке активной области, являлись результатом магнитных пересоединений вызванных выходом нового змеевидного магнитного потока и его взаимодействием с уже существующим магнитным полем или между магнитными петлями самого потока.

Ключевые слова: Солнце, активная область, бомба Эллермана, $\mathrm{H}_{\alpha}$-выбросы, магнитные пересоединения.

M. N. Pasechnik

Main Astronomical Observatory of the National Academy of Sciences of Ukraine, Kyiv, Ukraine

\section{SPECTRAL STUDY OF ACTIVE REGION SITE WITH ELLERMAN BOMB AND $\mathrm{H}_{\alpha}$-EJECTIONS. CHROMOSPHERE. ELLERMAN BOMB}

The results of the spectral observation analysis in the $\mathrm{H}_{\alpha}$ line of a site of active region NOAA 11024, on which the Ellerman bomb and various types of chromospheric ejections developed, are presented.The spectral data with high spatial and temporal resolution were obtained with the French-Italian solar telescope THEMIS on July 4, 2009. The observation time was 20 minutes. 400 spectra with a time interval of $\sim 3$ seconds were obtained. On the day of the observations, the AR was at the stage of a sharp increase in activity. Stokes I 
profiles were obtained, with an interval corresponding to $160 \mathrm{~km}$ on the surface of the Sun. The $\mathrm{H}_{\alpha}$ line profiles for different periods of the EB development were very diverse, generally they consisted of several components and were asymmetric with an excess of emission in the short-wavelength wing. The maximum increase in emission component intensity, in comparison with the profile for the $\mathrm{AO}$ area without active formations, in the short-wave by $73 \%$ and in the long-wave by $35 \%$ wings occurred at the distance of about $\pm 0.16 \mathrm{~nm}$ from the $\mathrm{H}_{\alpha}$ line core. The temporal variations of intensity in the $\mathrm{H}_{\alpha}$ line wings indicate that during the development of the Ellerman bomb a gradual release of energy took place during the first 8 minutes, and then a pulse release of energy for 6 minutes. The period of the EB brightness increase consisted of 5 peaks with an interval of about 1 minute. The temporal changes in the line-of-sight velocities $\left(V_{l o s}\right)$ of chromospheric matterthe over the region of EB development at the level of the $\mathrm{H}_{\alpha}$ line core formation, which we obtained, indicate that the distribution of velocities in this region was mainly caused by the development of chromospheric ejections. It was found that $V_{\text {los }}$ in the area without active formations varied within $\pm 2 \mathrm{~km} / \mathrm{s}$. Two periods of $V_{\text {los }}$ increase were distinguished, which consisted of several individual peaks — in the first half of the observations, the chromospheric matter mainly moved upward, and in the second half of the observations, the downward movement of matter prevailed. $\mathrm{H}_{\alpha}$-ejections of various types were observed over the area of EB development. The maximum velocity of upward movement in return ejections reached $-12 \ldots-16 \mathrm{~km} / \mathrm{s}$ and the chromospheric matter descended along the same trajectories of magnetic loops at a velocity twice as high - up to $22 \ldots 30 \mathrm{~km} / \mathrm{s}$. In a loop ejection, the chromospheric matter moved both up and down simultaneously. The maximum $V_{l o s}$ of the upward movement at one side of the loop was $-7 \mathrm{~km} / \mathrm{s}$, and the downward one at the other side of the loop reached $18 \mathrm{~km} / \mathrm{s}$. One of the ejections showed signs of plasma vortex motions, as evidenced by the inclined dark streaks in the spectra. The features of the change in the intensity of the $\mathrm{H}_{\alpha}$ line wings and the line-of-sight velocities of the chromospheric matter indicate that the Ellerman bomb and its accompanying $\mathrm{H}_{\alpha}$-ejections, which emerged and developed in the active region site under investigation, were the result of magnetic reconnections caused by the emergence of a new serpentine magnetic flux and its interaction with a pre-existing magnetic field or between the magnetic loops of the flux itself.

Keywords: Sun, active region, Ellerman bomb, $\mathrm{H}_{\alpha}$-ejections, magnetic reconnections.

Стаття надійшла до редакції 29.09.2020

Після доопрацювання 12.10.2020

Прийнята до друку 20.10.2020 